\title{
Building Institutions for the Common Good. The Practice and Purpose of Business in an Inclusive Economy
}

\author{
Martin Schlag ${ }^{1} \cdot$ Domènec Melé $^{2}$
}

Published online: 9 July 2020

(C) Springer Nature Switzerland AG 2020

Our world is increasingly fragmented. The post-war consensus on a politics of multilateral treatises and international cooperation in trade and commerce is being challenged by a new wave of protectionism and populism. The temptation of isolationism promises greater national or local wealth but ends up reducing the economy to a zero-sum game that leaves all participants poorer, except for a few privileged players. Mercantilism, trade wars, and even armed international conflict loom on the horizon. In such a socio-political environment, the topic of the common good in business and management, as antidote to egoistic individualism and proud self-aggrandizement, is of unabated interest and growing importance for humanistic management. The common good is a theme of reflection and study for business ethics, political philosophy, and other academic disciplines, and has many implications. It is especially relevant for humanistic management that "emphasizes common human needs and is oriented to the development of human virtue, in all its forms, to its fullest extent." (Melé 2003, 77).

The current crisis triggered by the COVID-19 pandemic has forced us to realize that we are all affected by the same diseases and the same cures. It has made it more necessary than ever to reflect not only on the local but also the universal common good, (see Bruno Dyck's essay in this special issue) understood as common need of all of us who increasingly are aware of being a global community.

Humanistic management does not only consider the individual but it aims at building communities because it considers business enterprise to be a community of persons. (Melé 2003, 82; Melé 2012) We possess a natural tendency to cooperate, out of necessity in a world of scarce resources and harsh environment but also out of the social nature of human beings. In

Domènec Melé

mele@iese.edu

Martin Schlag

sch12455@stthomas.edu

1 Alan W. Moss Endowed Chair for Catholic Social Thought, University of St. Thomas, St. Paul, MN 55105, USA

2 IESE Business School, University of Navarra, Av. Pearson, 21, 08034 Barcelona, Spain 
order to cooperate, we form communities, or rather we are born into and grow up in communities. Our lives do not make sense outside of communities. In order to be good institutions that promote human flourishing, communities need good governance and continuous care. (Moore 2017; Beabout 2012).

Communities are work in progress, and this fact challenges managers on a daily basis to motivate, enthuse, encourage, support, but also admonish and correct their coworkers. In a certain sense, management is a pastoral task. Thus humanistic management is essentially personalistic. (Acevedo 2012) It presupposes an understanding of the human being as person with dignity that cannot be completely submitted to the needs and wants of society and business, but at the same time is not an isolated monad that could abstain from contributing to the well-being of others. (Pirson 2017) It is this balance between the absolute self-worth of the human person and her rootedness in relationships which is expressed in the AristotelianThomist tradition as it was received by Catholic social thought. (see Giulio Maspero's essay in this special issue).

For Aristotle, the common good is the life in common in the Greek city-state. It is thus the good of the polis and of its citizens who can only achieve their own fulfillment and flourishing in the polis. Aquinas transfers the Aristotelian conception into a Christian worldview, in which God is the overall common good of the whole of creation. (Sison and Fontrodona 2012, 213-216) However, for the temporal government of earthly communities, the political common good in Aquinas is justice and peace. (Schlag 2017) Developing out of these intellectual roots, in the Catholic social tradition the common good is usually defined as "the sum of those conditions of social life which allow social groups and their individual members relatively thorough and ready access to their own fulfillment" (Vatican Council II 1965a, n. 26) This notion of the common good is far from both the individualistic-utilitarian view, which understands the common good as the sum of individual interests, and its collectivistic version, in which personal freedom practically disappears. The definition by the Second Vatican Council mentioned above underscores that the notion of human flourishing is linked both to communities and to the personal sphere of individual self-realization. It does not mention freedom explicitly, but presupposes it: how could we achieve our own fulfillment in a system of repression and totalitarianism? It is thus in the context of a free society, that the common good according to Catholic social thought can best be achieved. Peace, freedom, and justice, are thus the central values that constitute the common good in this tradition. (Vatican Council II 1965b, n. 6) Freedom needs to be linked to the truth of human nature. There are actions we can freely choose that destroy life in common. Murder of innocent people, theft, lies, and other acts that turn against the human person are not an expression of true freedom. Freedom that becomes destructive of self and others, is not real freedom but simply free choice. In order to lead to flourishing, human practices need to conform to a standard of human excellence that we traditionally call virtue. Human work in business can be a school of virtue; and management plays an essential role by creating good institutions, good companies and firms that allow virtuous practices to develop.

Sison and Fontrodona (2013) have defined the common good of the business firm "as collaborative work, insofar as it provides, first, an opportunity to develop knowledge, skills, virtues, and meaning (work as praxis), and second, inasmuch as it produces goods and services to satisfy society's needs and wants (work as poiesis)." These authors rightly point out that not only does business contribute to the common good of society but the firm itself has a common 
good of its own. They describe the common good of the firm as "'intrinsic', 'social', and 'practical'." (Sison and Fontrodona 2013, 612) 'Intrinsic' because collaborative work that constitutes the common good of the firm cannot exist outside of the firm; 'social' because it depends on a community acting together; and 'practical' because the common good of collaboration is an activity and not a theory alone. The common good of a firm requires the participation of all its members. What Sison and Fontrodona do not sufficiently consider, are the consequences of the distinction between praxis and poiesis on the notion of the common good. The extrinsic common goods of the firm are its products and services that are goods in plural and can be divided. The intrinsic common good of the firm is its character as a community of persons. It is in singular, and cannot be divided. This distinction is similar to the common good of a married couple. In the case of divorce, they can split up the material goods (houses, cars, pets, etc.) but not the good of being together. The intrinsic common good of marriage is lost through divorce because it is indivisible. A consequence of this vision is that the common good is also inclusive of all those who belong to a community. The unjust exclusion of a member would mortally wound the common good of that community. This idea we can refer to as inclusivity.

In this Special Issue, we wish to reflect on the inclusivity of business institutions in an ethical sense. Inclusivity of businesses and of the economy as a whole have become a focus of interest. (OECD 2014; Rajan 2019) Here we present articles that reflect both on the institutional consequences of the inclusivity of the common good inside business firms and its implications for the economy as a whole.

Discussing the role of the common good in the firm is not new. The oldest bibliographical references on business and the common good go back to the 1980s. Some of them are about the common good as a fundamental orientation for Corporate Social Responsibility (Gallo 1980; Mahon and McGowa 1991; Alford and Shcherbinina 2008) and international commerce (Velasquez 1992). Others have focused on the common good as the purpose of the firm (Naughton et al. 1995; Alford and Naughton 2001, 2002; Gates 2002, Melé 2002; Sison and Fontrodona 2012), or as fundamental element for understanding or managing business enterprises (Kangas 1983, Fort 1999; Naughton 2006; Kennedy 2006, 2007; Koslowski 2006; Sison 2007, Melé 2009, 2012) and have used the common good to develop the stakeholder theory (Argandoña 1998). In recent years, scholars have continued to work on different aspects highlighting the relevance of the common good in economics and business (Zamagni 2008; Melé 2009; O'Brien 2009; Alexander and Buckingham 2011; Martin 2011; Schlag and Mercado 2012; Rhonheimer 2012; Pinto 2015; Costa and Ramus 2012; Gustafson 2013; Sison 2013; Wong and Rae 2011; Frémeaux and Michelson 2017; Tirole 2017, Arjoon et al. 2018; to mention a few). However, much work still needs to be done to elucidate the implications of the common good for the design of institutions, including business organizations. This motivated the organization of the tenth international conference on Catholic Social Thought in Business Education conjointly with the sixth international Colloquium on Christian Humanism in Business and Society "Building Institutions for the Common Good: the Practice and Purpose of Business in an Inclusive Economy" in Minneapolis, USA, in 2018. The special issue is a selected collection of papers presented in this event, and thoroughly revised afterwards, as well as of articles written especially for this issue.

In the first article, Bruno Dyck discusses the implications of the integral common good for seven key practices of humanistic management. After discussing the notion of an integral common good, he shows how an approach based on it can make conventional 
management more humanistic by bringing fair treatment of individuals in play with communities that nurture relationships.

Giulio Maspero supplies a further theoretical foundation for the importance of a relational view of the human person for humanistic management. He adeptly combines the existence of Gemeinschaft and Gesellschaft in business organizations, showing how the interior conversation in us influences our relationships and interactions.

Mariana HC Gonstead and Rachana Chhin focus on the unique gift with which every member of an organization contributes to its common good. The authors advocate for a shift form a mindset of independence to a mindset of interdependence that unlocks the organization's collective potential. To this end, the authors propose a participatory framework that they call Shared Decision System Design.

In the article "Embedding Humanizing Cultures in Organizations through 'Institutional' Leadership", Massimiliano Monaci argues that human resource management can provide essential support for the development of an organizational culture in conformity with human dignity. Managers acting as institutional leaders can contribute to the embedding of moral identities in the organizational context. He draws on Catholic social teaching in developing his view of the firm as a community of work, where "organizational humanizing cultures" can be developed that revolve around the principles of human dignity and the common good and on the 'institutional leadership' proposed by Philip Selznick.

Kenneth W. Stikkers presents the worker-owned Mondragon Cooperatives as an example of how the common good in economic life can be institutionalized. He contrasts the notion of the common good of Catholic social teaching as it is realized in the Mondragon cooperatives with the notion of the common good as the sum of individual goods, or aggregate utility as used by neoclassical economics. The paper also describes how participation in the cooperatives engenders, cultivates, and deepens worker-members' sense and understanding of the common good and their commitment to it.

The Special Issue continues with an article by Dung Q. Tran and Larry C. Spears on leadership. They argue that leadership aims first and foremost at the common good of the business, not only at the individual advantage of the manager. Without this kind of leadership, management could not build good inclusive economic institutions. They examine how Robert K. Greenleaf's vision of servant-leadership is embodied in the life and work of Saint John XXIII. The similarity between the position of John XXIII and that of Greenleaf is based on their notion of human dignity and the common good.

Bruce D. Baker and Don Lee argue that solidarity is vitally important to the practice of humanistic management, since it contributes to communities of work with a common good. Through empirical research (a survey at 40 workplaces and among 399 employees in public and private organizations) the authors show that there is a positive association between solidarity and workplace engagement. Drawing from the findings, the authors give suggestions for practicable, tangible workplace behaviors and offer guidance in the pursuit of this aspect of humanistic management.

Abigail B. Schneider and Daniel P. Justin present an educational experience of how to help future business leaders to build virtuous institutions for the common good. Their point of departure are individualistic versions of social entrepreneurship that they wish to develop in a humanistic sense by cultivating a mindset of relationality. 


\section{References}

Acevedo, A. 2012. Personalist business ethics and humanistic management: Insights from Jacques Maritain. Journal of Business Ethics 105 (2): 197-219.

Alexander, J.M., and J. Buckingham. 2011. Common good leadership in business management: An ethical model from the Indian tradition. Business Ethics: A European Review 20 (4): 317-327.

Alford, H.J., and M.J. Naughton. 2001. Managing as if faith mattered. Christian social principles in the modern organization. Notre Dame: Notre Dame University Press.

Alford, H., and M. Naughton. 2002. Beyond the shareholder model of the firm: Working toward the common good of a business. In Rethinking the purpose of business. Interdisciplinary essays from the Catholic social tradition, ed. S.A. Cortright and M. Naughton, 27-47. Notre Dame: Notre Dame University Press.

Alford, H. \& Shcherbinina, Y. 2008. Corporate social responsibility and the common good. In E. Bettini and F. Moscarini (Eds.), Responsabilità Sociale d'Impresa e Nuovo Umanesimo (pp. 14-30). Genoa: San Giorgo Editrice.

Argandoña, A. 1998. The stakeholder theory and the common good. Journal of Business Ethics 17: 1093-1102.

Arjoon, S., A. Turriago-Hoyos, and U. Thoene. 2018. Virtuousness and the common good as a conceptual framework for harmonizing the goals of the individual, organizations, and the economy. Journal of Business Ethics 147: 143-163.

Beabout, G. 2012. Management as a domain-relative practice that requires and develops practical wisdom. Business Ethics Quarterly 22 (2): 405-432.

Costa, E., and T. Ramus. 2012. The Italian Economia Aziendale and Catholic social teaching: How to apply the common good principle at the managerial level. Journal of Business Ethics 106 (1): 103-116.

Fort, T.L. 1999. The first man and the company man: The common good, transcendence, and mediating institutions. American Business Law Journal 36 (3): 391-435.

Frémeaux, S., and G. Michelson. 2017. The common good of the firm and humanistic management: Conscious capitalism and economy of communion. Journal of Business Ethics 145 (4): 701-709.

Gallo, M.A. 1980. Responsabilidades sociales de la empresa. Pamplona: Eunsa.

Gates, J. 2002. Reengineering ownership for the common good. In Rethinking the purpose of business. Interdisciplinary Essays from Catholic social tradition, ed. S.A. Cortright and M.J. Naughton, 264-288. Notre Dame: Notre Dame University Press.

Gustafson, A. 2013. Business for the common good: A Christian vision for the marketplace. Business Ethics Quarterly 23 (1): 645-658.

Kangas, J.E. 1983. Compatible human communities: The role of ethics in modern Enterprise. Journal of Business Ethics 2 (2): 127-133.

Kennedy, R.G. 2006. Corporations, common goods, and human persons. Ave Maria Law Review 4 (1): 1-32.

Kennedy, R.G. 2007. Corporations, Common Goods, and Persons. Avemaria Law Review, 4(1), 1-32.

Koslowski, P. 2006. The common good of the firm as the fiduciary duty of the manager. In Global perspectives on the ethics of corporate governance, ed. G.J. Rossuw and A.J. Sison, 67-76. New York: PalgraveMacMillan.

Mahon, J.F., and McGowan, R.A. (1991). Searching for the common good: a process-oriented approach. Business Horizons 34 (4), 79-86.

Martin, F. 2011. Human development and the pursuit of the common good: Social psychology or Aristotelian virtue ethics? Journal of Business Ethics 100 (Supplement 1): 89-98.

Melé, D. 2002. Not only stakeholders interests: The firm oriented towards the common good. In Rethinking the purpose of business. Interdisciplinary essays from Catholic social tradition, ed. S.A. Cortright and M.J. Naughton, 190-214. Notre Dame: Notre Dame University Press.

Melé, D. 2003. The challenge of humanistic management. Journal of Business Ethics 44 (44): 77-88.

Melé, D. 2009. Integrating personalism into virtue-based business ethics: The Personalist and the common good principles. Journal of Business Ethics 88 (1): 227-244.

Melé, D. 2012. The Firm as a "Community of Persons": A Pillar of Humanistic Business Ethos. Journal of Business Ethics 106 (1): 89-101.

Moore, G. 2017. Virtue at work: Ethics for individuals, managers, and organizations. Oxford: Oxford University Press.

Naughton, M.J. 2006. The corporation as a community of work: Understanding the firm within the Catholic social tradition. Ave Maria Law Review 4 (1): 33-75.

Naughton, M., Alford, H. and Brady, B. 1995. The common good and the purpose of the firm. Journal of Human Values 1 (2): 221-237.

O'Brien, T. 2009. Reconsidering the common good in a business context. Journal of Business Ethics 85 (Supplement 1): 25-37. 
OECD. 2014. All on board: Making inclusive growth happen. Final report Available at https://www.oecd. org/inclusive-growth/All-on-Board-Making-Inclusive-Growth-Happen.pdf. Accessed 8 July 2020.

Pinto, J. 2015. The concept of work in a common good theory of the firm. Business \& Professional Ethics Journal 34 (1): 45-70.

Pirson, M. 2017. Humanistic management. Protecting dignity and promoting well-being. Cambridge: Cambridge University Press.

Rajan, R. 2019. The third pillar: How markets and the state leave the community behind. New York: Pinguin Press.

Rhonheimer, M. 2012. Capitalism, free market economy and the common good: The role of the state in the economy. In Free markets and the culture of common good, ed. M. Schlag and J.A. Mercado, 3-40. Heidelberg: Springer.

Schlag, M. 2017. The business Francis means: Understanding the Pope's message on the economy. Washington, D.C.: The Catholic University of America Press.

Schlag, M., and J.A. Mercado, eds. 2012. Free markets and the culture of the common good. Heidelberg: Springer.

Sison, A. 2013. Aristotle and the corporation. In C. Lüetge (Eds.), handbook of the philosophical foundations of business ethics (pp. 45-66). Heidelberg, Germany: Springer.

Sison, A.J.G. 2007. Toward a common good theory of the firm: The Tasubinsa case. Journal of Business Ethics 74 (4): 471-480.

Sison, A.J.G., and J. Fontrodona. 2012. The common good of the firm in the Aristotelian-Thomistic tradition. Business Ethics Quarterly 31 (2): 211-246.

Sison, A., and J. Fontrodona. 2013. Participating in the common good of the firm. Journal of Business Ethics 113 (4): 611-625.

Tirole, J. 2017. Economics for the common good (French original: Économie du bien commun. Paris: Presses Universitaires de France, 2016). Princeton, NJ, and Woodstock, United Kingdom.

Vatican Council II. 1965a. Pastoral constitution 'Gaudium et spes'. Available at http://www.vatican. va/archive/hist_councils/ii_vatican_council/documents/vat-ii_const_19651207_gaudium-et-spes_en.html. Accessed 8 July 2020.

Vatican Council II. 1965b. Declaration 'Dignitatis Humanae'. Available at: http://www.vatican.va/archive/hist councils/ii_vatican_council/documents/vat-ii_decl_19651207_dignitatis-humanae_en.html. Accessed $\overline{8}$ July 2020.

Velasquez, M. 1992. International business, morality and the common good. Business Ethics Quarterly 2 (1): $27-40$.

Wong, K., and S. Rae. 2011. Business for the common good: A Christian vision for the marketplace. Downers Grove: InterVarsity Press.

Zamagni, S. 2008. Reciprocity, civil economy, common good. In Pursuing the common good, ed. M. Archer and P. Donati, 467-502. Vatican City: The Pontifical Academy of Social Sciences.

Publisher's Note Springer Nature remains neutral with regard to jurisdictional claims in published maps and institutional affiliations. 